\title{
Acknowledgement to assessors
}

We are grateful to the following, who acted as expert assessors of manuscripts in 2008.

\begin{tabular}{|c|c|c|c|c|}
\hline G. Abbate Daga & M. Birchwood & T. Cannon & T. Croudace & M. Ernst \\
\hline A. Abrantes & J. Bisson & A. Cano & E. Csipke & J. I. Escobar \\
\hline J. Addington & J. Blair & E. Cantor-Graae & M. Cuesta & A. Etkin \\
\hline J. Addington-Hall & C. Blanco & C. Carter & A. Dahl & U. Ettinger \\
\hline A. Adewuya & R. Bland & A. Caspi & C. Dalman & H. P. Falkai \\
\hline E. Albanese & M. Blank & C. Castro & A. Danese & A. Fanous \\
\hline M. Alegria & D. Blazer & M. Catani & J. Davidson & A. Farmer \\
\hline A. Aleman & D. Blonigen & C. Chaddock & M. Davies & G. Fava \\
\hline B. A. Alford & J. Bobes & T. Chalder & P. Dazzan & A. Favaro \\
\hline L. Ali & P. Boelen & C. M. Chen & R. De Graaf & J. Fawcett \\
\hline P. Allen & M. Bohus & C.-N. Chen & M. De Rover & P. Fearon \\
\hline F. Amaddeo & D. Bolton & E. Chen & K. Dean & I. Federenko \\
\hline T. Amos & S. Bonaccorso & W. Chen & Q. Deeley & A. Feinstein \\
\hline H. Anckarsater & G. Bond & Y. Chen & J. R. DePaulo & D. Fergusson \\
\hline I. Anderson & K. Boutell & A. Cheng & E. M. Derks & E. Fergusson \\
\hline G. Andersson & P. Brambilla & J. Chick & M. deWaal & F. Fernández- \\
\hline L. Andrade & G. Breen & S. Chua & D. Dick & Aranda \\
\hline J. G. Andrews & D. Brent & G. Claridge & M. Diego & S. Ferrando \\
\hline A. Angold & J. Breslau & L. Clark & M. diForti & N. Ferrier \\
\hline J. Anthony & N. Breslau & M. Clarke & T. Dinan & E. Fertuck \\
\hline M. Arendt & T. Brewerton & A. Cleare & T. Ditman & J. Feusner \\
\hline S. Argyropoulos & C. Brewin & C. R. Cloninger & N. Docherty & D. Finkel \\
\hline B. Arnow & J. Britton & D. Coghill & B. Dohrenwend & M. First \\
\hline P. Asherson & E. Bromet & P. Cohen & C. Dolan & E. Fischer \\
\hline M.-C. Asselin & A. Brooks & J. Coid & A. Dombrovsky & D. Fishbain \\
\hline G. August & M. Broome & H. Conradi & G. Domes & A. Fiske \\
\hline R. Baillargeon & A. Brown & Y. Conwell & J. Dowson & J. Fiszden \\
\hline L. Baker & C. Brown & D. Cooke & A. Doyle & S. Fleminger \\
\hline D. Baldwin & G. Brown & C. Cooper & F. Doyle & P. Fletcher \\
\hline R. Baldwin & R. Brown & M. Cooper & R. Drake & J. Ford \\
\hline H. Ball & S. Brown & P. Cooper & D. D'Souza & T. Ford \\
\hline C. Barbui & K. Bruce & P. Corcoran & P. Dudgeon & P. Fossati \\
\hline J. Barnett & S. Bruce & P. Corlett & R. Dutta & D. Fowler \\
\hline N. Barrantes & M. Bruene & B. Cornblatt & D. Ebert & E. Frank \\
\hline C. Barrowclough & A. Brunet & P. Corrigan & K. Ebmeier & F. Frankenburg \\
\hline J. Bayless & R. Bryant & E. J. Costello & U. Ebner-Priemer & K. Freedland \\
\hline S. Beach & A. Buchanan & J. Costello & G. Edwards & D. Freeman \\
\hline C. Bearden & R. Buchanan & A. Cougnard & M. Edwards & R. Freeman \\
\hline A. Beautrais & C. Bulik & L. Covey & A. Ehlers & B. Friedman \\
\hline P. Bech & E. Bullmore & P. Cowen & V. Elderkin- & S. Friis \\
\hline E. Bell & B. Bunting & S. Cowman & Thompson & C. Frith \\
\hline R. Beninger & A. Burns & N. Craddock & T. Eley & L. Frölich \\
\hline J. Bensing & T. Burns & I. Craig & M. Ellenbogen & T. Fryers \\
\hline R. Bentall & T. Button & K. Craig & R. Elliott & C. Fu \\
\hline H. Bergen & G. Byrne & T. Craig & C. Ellison & R. Fuhrer \\
\hline J. Biederman & M. Calkins & C. Craver & B. Elvevag & A. Fyer \\
\hline O. J. Bienvenu & I. Campbell & M. Crawford & R. Emsley & J. Gaab \\
\hline A. Bifulco & G. Canino & B. Crespo-Facorro & P. Enright & R. Gafoor \\
\hline E. Binder & M. Cannon & H. Critchley & K. Erickson & B. Gallhofer \\
\hline
\end{tabular}




M. Ganguli
P. Garety
E. Garralda
L. Gask
J. Geddes
J. Gelllatly
M. George
S. N. Ghaemi
B. Gibb
S. Gilbody
M. Gill
N. Gillespie
S. Gilman
D. Gimeno
N. Gogtay
M. Goldacre
E. Goldbacher
D. Goldberg
L. Goldstein
S. Goldstein
D. Goldston
D. Gooding
G. Goodwin
I. Goodyer
I. Gottesman
E. Griez
J. Grisham
A. Grrenberg

A. Gruenberg J. Guidi

A. Gumley

H. Gundel

J. Gunn

D. Gunnell

J. Gunstad

O. Gureje

H. Gurling

J. Hall

M.-H. Hall

S. Halligan

J. Hamalainen

C. Hammen
A. Hardan
R. Harland
C. Harmer
G. Harrison
P. Harvey
G. Hasler
E. Hawkins
D. Healy
R. Heaton
J. Hektner
E. Hembree
A. S. Henderson
C. Henquet
M. Heo

S. Herpertz
J. Hettema
W. Hiller
B. Hitsman
M. Hodes
S. Hodgins
S. Hoffman
S. Hollon
D. Holt
P. Holtzheimer
R. Honea
R. Hoste
M. Hotopf
A. House
L. Howard
C. Hulbert
G. Humphris
F. Huppert

M. Keller

J. W. Kemnitz

R. Kessler

M. King

D. Kingdon

T. Kircher

J. Kirkbride

I. Kirsch

P. Kirsch

C. Klein

D. Klein

K. Klump

K. Koenen

J. S. Kooij

W. Kop

L. Krabbendam

E. Kravariti

A. Kring

N. Husain

W. Iacono

E. Iacoponi

M. Ilgen

R. Ingram

E. Isometsa

A. Jablensky

H. Jackson

G. Jacob

K. Jacob

F. Jacobi

K. Jacobson

A. Jaffa

S. Jain

A. James

D. James

R. Jarrett

D. Javitt

R. Jenkins

L. Johns

S. Johnson

E. Johnstone

P. Jones

A. Jorm

E. Joyce

G. Juckel

L. Judd

D. Kaloupek

D. Kaminsky

R. Kanaan

D. Kandel

E. Kane

A. Kaptein

S. Kapur

A. Karwautz

R. Keefe

P. Keel
K. Kroenke

E. Kua

C. Kuehner

E. Kuipers

V. Kumari

P. Kuo

G. Kuperberg

B. Kurian

H. Lacey

D. Lang

K. Lange

F. Laroi

T. Laursen

C. Lavie

A. Lawrence

S. Lawrie

Y. Lecrubier

K.-H. Lee

S. Lee

$W$. Lee

E. Leibenluft

P. Lelliott

E. Lemche

B. Lennox

S. Leucht

J. Levenson

A. Leventhal

D. Levinson

L. Levita

J. Levitt

D. Levy

S. Lewis

G. Lewison

R. Liberman

P. Lichtenstein

E. Liebenluft

J. Lieberman

\section{G. Light \\ J. Lindesay \\ $X$. Liu \\ E. Lloyd- \\ Richardson \\ J. Lonnqvist \\ N. Low \\ G. Lubke \\ M. Luciana \\ M. Lumley}

W. Lutz

M. Lynskey

J. MacLeod

A. Maden

J. Magee

W. Maier

A. Malizia

A. Malla

S. Marder

K. Markon

I. Marks

C. Marmar

A. Marneros

N. Martin

S. Marwaha

D. Mataix-Cols

K. Matsumoto

K. Matsuo

S. Mazzeo

H. McAllister-

Williams

J. McAvoy

J. McCabe

R. McCabe

D. McChargue

J. McClellan

R. McCrae

R. McDonald

J. McGough

J. McGrath

M. McGue

P. McGuffin

P. McGuire

P. McKenna

K. McKenzie

A. McKintosh

B. McLeod

D. McLoughlin

M. McMurran

T. McNeil

L. McWilliams

C. Meade

A. Mechelli

M. Mehta

H. Meltzer
D. Melzer

M. Menon

L. Menzies

K. Merikangas

B. Meyers

P. Michalopoulou

E. Mick

C. Middledorp

M. Milad

S. Miles

A. Miller

T. Miller

G. Milos

H. Minnis

T. Moffitt

J. Moncrieff

V. Mondelli

S. Monroe

S. Moorey

P. Moran

S. Morein-Zamir

C. Morgan

K. Morgan

V. Morgan

S. Moritz

E. Moscicki

K. Mueser

R. Mulder

P. Mullen

D. Murphy

L. Murray

I. Myin-Germeys

J. Neeleman

G. Nestadt

J. Newman

M. Niznikiewicz

M. Nordentoft

C. Norra

S. Norrholm

M. Norton

A. Nugent

B. O'Donnell

M. O'Donnell

J. O'Brien

R. O'Carroll

R. O'Connor

T. O'Connor

M. Olff

T. Oltmanns

F. A. O'Niell

J. Ormel

M. Orrell

D. Owens

S. Palmen

B. Palmer 


\begin{tabular}{|c|c|c|c|c|}
\hline A. Parabiaghi & M. Reveley & A. Shah & J. Suvisaari & M. Wainberg \\
\hline S. Park & M. Richards & M. Sharpe & K. Szanto & I. D. Waldman \\
\hline G. Parker & K. Rickels & J. Shaw & G. Szmukler & B. T. Walsh \\
\hline J. Parnas & W. Rief & P. Shaw & P. Tabraham & D. Walsh \\
\hline V. Patel & F. Rijsdijk & M. Shenton & J. Tackett & E. Walsh \\
\hline C. Paton & G. Rippon & S. Shi & M. Tansella & M. Walshe \\
\hline M. Paulus & K. Ritchie & L. Shin & N. Tarrier & G. Walter \\
\hline S. Pawlby & T. Robbins & P. Shrout & N. Taub & J. Waltz \\
\hline E. Paykel & R. Roberson-Nay & L. Siedman & M. Taylor & G. J. Wang \\
\hline S. Payne & B. Rodgers & R. Siegert & J. Taylor-Tavares & P. Wang \\
\hline C. Pedersen & C. Rodgers & J. Silberg & K. Tchanturia & D. Warman \\
\hline V. Peralta & R. Rodriguez- & K. Silk & B. Teachman & E. R. Watkins \\
\hline R. Peveler & Jimenez & D. Silove & G. Thaker & L. Watkins \\
\hline L. Pezawas & J. Roiser & A. Simmons & K. Thakkar & D. Watson \\
\hline K. Phillips & R. Rona & G. Simon & J. Thakore & P. Watson \\
\hline M. Phillips & S. Rosenman & E. Simonoff & P. Tharyan & J. Weinman \\
\hline D. Pine & R. Roth & S. Singh & M. Thase & M. Weissman \\
\hline J. Pirkis & A. Roy & S. Sinha & J. Thomas & J. Welham \\
\hline J. Piven & J. Rubinsztein & T. Sitnikova & B. Thombs & A. Wells \\
\hline D. Pizzagalli & M. Ruggeri & A. Skodol & D. Thompson & S. Wessely \\
\hline G. Ploubidis & A. Ruscio & N. Slopen & L. Thomson & P. White \\
\hline J. Poling & A. J. Rush & S. Smalley & E. Tomba & J. Whitlock \\
\hline P. Politi & F. Ruths & I. Sommer & L. Tondo & P. Wickramaratne \\
\hline R. Poulton & M. Rutter & V. Spek & T. Topolski & B. Wiffen \\
\hline P. Power & P. Sachdev & S. Spence & S. Tosato & H. Wilcox \\
\hline N. Poythress & J. Sadler & S. Stansfeld & T. Toulopoulou & C. Williams \\
\hline D. Prata & R. Sainz & S. Starkstein & M. Tournier & G. V. Williams \\
\hline C. Prescott & P. Salmon & J. Starr & F. Tozzi & M. Williams \\
\hline S. Priebe & R. Salokangas & M. Startup & J. Treasure & H.-U. Wittchen \\
\hline L. Pulkki-Råback & V. Sansone & D. Steele & P. Trower & P. Woodruff \\
\hline J. Puymirat & A. Santhouse & D. Steffens & D. Turkington & T. Woodward \\
\hline B. Quednow & J. Sareen & M. Stein & C. Turvey & L.-T. Wu \\
\hline F. Raes & J. Savitz & J. Steinglass & A. Tuulio- & S. Wust \\
\hline A. Rahman & U. Schall & B. Stephan & Henriksson & J. Yager \\
\hline R. Ramana & A. Schene & K. Stephan & R. Uher & P. Yip \\
\hline C. Randall & J. E. Schmitt & A. Steptoe & L. Valmaggia & J. Yoon \\
\hline J. Rapoport & N. Schmitz & E. Stern & M. Van Aken & A. Young \\
\hline M. Rapoport & J. Schneider & R. Stewart & G. T. Vance & W. Yule \\
\hline M. Rashed & U. Schnyder & J. Stirling & M. Van der Gaag & A. Yung \\
\hline A. Raznahan & G. Schomerus & S. Stoltenberg & G. Van der Linden & P. Zachar \\
\hline J. Read & K. Schruers & W. Stone & D. Van Grootheest & M. Zanarini \\
\hline Y. C. J. Reddy & B. Schulze & G. Stoppe & K. Van Heeringen & M. Zimmerman \\
\hline D. Redhead & T. Schulze & T. Straube & J. Van Os & R. Zipursky \\
\hline A. D. Redish & J. Scott & M. Strober & N. Vasic & S. Zisook \\
\hline D. Regier & K. Scott & K.-P. Su & J. Veijola & A. Zohar \\
\hline T. Reichborn- & Z. Segal & M. Sullivan & H. Verdoux & J.-K. Zubieta \\
\hline Kjennerud & T. Sensky & P. Sullivan & E. Viding & \\
\hline A. Reichenberg & A. Serretti & S. Surguladze & N. Vogelszangs & \\
\hline U. Reininghaus & D. Shaffer & E. Susser & T. Wade & \\
\hline
\end{tabular}




\section{CAMBRIDGE JDURNALS}

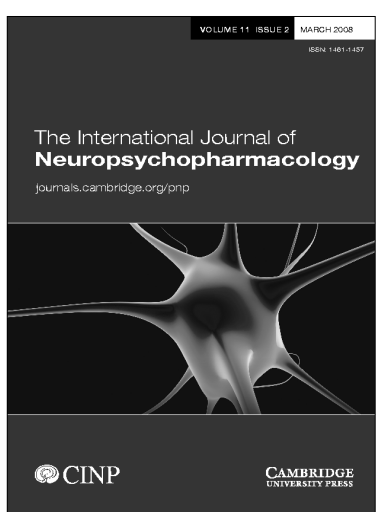

The International Journal of Neuropsychopharmacology is available online at

journals.cambridge.org/pnp

To subscribe contact Customer Services

\section{in Cambridge:}

Phone +44 (0)1223 326070

Fax +44 (0)1223 325150

Email journals@cambridge.org

in New York:

Phone (845) 3537500

Fax (845) 3534141

Email

subscriptions_newyork@cambridge.org

\section{The International} Journal of

Neuropsychopharmacology

The official scientifc journal of the Collegium Internationale Neuro-Psychopharmcologicum (CINP)

\section{Editor-in-Chief}

Alan Frazer, San Antonio, USA

The International Journal of Neuropsychopharmacology (IJNP) serves as a major forum for the rapid publication and dissemination of high quality research in

neuropsychopharmacology. The focus of the journal is on research which advances understanding of existing and new neuropsychopharmacological agents, including their mode of action and clinical application, or which provides insights into the biological basis of neuropsychiatric disorders and thereby advances their pharmacological treatment.

Price information is available at journals.cambridge.org/pnp

\section{Free email alerts}

Keep up-to-date with new material sign up at journals.cambridge.org/register 


\section{INSTRUCTIONS FOR CONTRIBUTORS}

PAPERS Papers for publication from Europe and Australasia, except those on genetic topics, should be addressed to the UK Editor, Professor Robin M Murray, Psychological Medicine Editorial Office, Douglas House, 18E Trumpington Road, Cambridge CB2 8AH, UK, E-mail: Igs21@cam.ac.uk. Papers from the Americas, Asia, Africa and the Middle East, and all papers dealing with genetic topics, irrespective of country, should be sent to the US Editor, Professor Kenneth S Kendler, MCV, PO Box 980126, Richmond, VA, 23298-0126, USA (Street address: Virginia Biotechnology Center One, Room 1-123, 800E Leigh Street, Richmond, VA, 23219, USA), Email: bherrmann@vcu.edu.

Submissions by email attachments are preferred. Alternatively contributors who wish may send one hard copy of the text, tables and figures, plus an identical copy on computer disk, giving details of format used (e.g. MS Word etc.). Authors should also accompany their submission with a list of 5 or more suggested suitable referees to aid the peer review process.

A covering letter signed by all authors should confirm agreement to submission. The letter should also give full mailing, fax and email contact details of the author who will handle correspondence. Submission of a paper will be held to imply that it contains original work that has not been previously published and that it is not being submitted for publication elsewhere. This should be confirmed in the letter of submission. When an article has been accepted for publication, the authors should email their final version or send a copy on computer disk (indicating format used, e.g. Mac/PC, MS Word/Word Perfect, etc.) together with one hard copy of the typescript and good quality copies of all tables, figures, etc. However, the publisher reserves the right to typeset the material by conventional means if an author's disk proves unsatisfactory.

The following information must be given on the first page (title sheet): (1) title and short title for running head (not more than 60 characters): (2) authors' names, (3) department in which the work was done, (4) word count of text excluding abstract, tables/figures and reference list. Generally papers should not have text more than 4500 words in length (excluding these sections) and should not have more than a combined total of 5 tables and/or figures. Papers shorter than these limits are encouraged. For papers of unusual importance the editors may waive these requirements. A structured abstract of no more than 250 words should be given at the beginning of the article using the headings: Background; Methods; Results; Conclusions. The name of an author to whom correspondence should be sent must be indicated and a full postal address given in the footnote. Any acknowledgements should be placed at the end of the text (before the References section).

Declaration of Interest: A statement must be provided in the acknowledgements listing all financial support received for the work and, for all authors, any financial involvement (including employment, fees, share ownership) or affiliation with any organization whose financial interests may be affected by material in the manuscript, or which might potentially bias it. This applies to all papers including editorials and letters to the editor.

Contributors should also note the following:

1. S.I. units should be used throughout in text, figures and tables.

2. Authors should spell out in full any abbreviations used in their manuscripts.

3. Foreign quotations and phrases should be followed by a translation.

4. If necessary, guidelines for statistical presentation may be found in: Altman DG, Gore SM, Gardner MJ \& Pocock SJ (1983). Statistical guidelines for contributors to medical journals. British Medical Journal 286, 1489-1493.

REFERENCES (1) The Harvard (author-date) system should be used in the text and a complete list of References cited given at the end of the article. In a text citation of a work by more than two authors cite the first author's name followed by et al. (but the names of all of the authors should be given in the References section). Where several references are cited together they should be listed in rising date order. (2) The References section should be supplied in alphabetical order (authors' names in bold, journal titles in full), following the text. Some examples follow:

Miller PM, Byrne M, Hodges A, Lawrie SM, Johnstone EC (2002). Childhood behaviour, psychotic symptoms and psychosis onset in young people at high risk of schizophrenia: early findings from the Edinburgh high risk study. Psychological Medicine 32, 173-179.

Cleckley HJ (1941). The Mask of Sanity, 2nd edn. Mosby: St. Louis, MO.

Brewer WJ, Wood SJ, DeLuca C, Pantelis C (2006). Models of olfaction for exploring neurodevelopment. In Olfaction and the Brain (ed. W. J. Brewer, D. Castle and C. Pantelis), pp. 97-121. Cambridge University Press: Cambridge.

(3) Online citations

doi (when published online prior to printed issue)

Lauritsen MB, Pedersen CB, Mortensen CB (2004). The incidence and prevalence of pervasive developmental disorders: a Danish population-based study. Psychological Medicine. Published online: 21 October 2004. doi:10.1017/ S0033291704002387.

$U R L$

World Bank (2003). Quantitative techniques for health equity analysis - Technical Notes (http://siteresources.worldbank. org/INTPAH/ Resources/Publications/Quantitative-Techniques/health.eq tn07.pdf). Accessed 15 February 2006.

[Authors are requested to print-out and keep a copy of any online-only material, in case the URL changes or is no longer maintained.]

FIGURES AND TABLES Only essential figures and tables should be included. Further tables, figures, photographs and appendices, may be included with the online version on the journal website. To ensure that your figures are reproduced to the highest possible standards, Cambridge Journals recommends the following formats and resolutions for supplying electronic figures. Please ensure that your figures are saved at final publication size and are in our recommended file formats. Following these guidelines will result in high quality images being reproduced in both the print and the online versions of the journal. Line artwork: Format: tif or eps, Colour mode: black and white (also known as 1-bit), Resolution: $1200 \mathrm{dpi}$; Combination artwork (line/tone): Format: tif or eps, Colour mode: grayscale (also known as 8-bit), Resolution: 800 dpi; Black and white halftone artwork: Format: tif, Colour mode: grayscale (also known as 8-bit), Resolution: 300 dpi; Colour halftone artwork: Format: tif, Colour mode: CMYK colour, Resolution: $300 \mathrm{dpi}$. All photographs, graphs, and diagrams should be referred to as figures and should be numbered consecutively in Arabic numerals. Captions for figures should be typed double-spaced on separate sheets. Tables Tables should be numbered consecutively in the text in Arabic numerals and each typed on a separate sheet after the References section. Titles should be typed above the table.

PROOFS AND OFFPRINTS Page proofs will be sent to the author designated to receive correspondence. corrections other than to printer's errors may be charged to the author. Fifty offprints of each paper are supplied free; additional offprints are available according to a scale of charges if they are ordered on the form supplied when the proof is returned. 


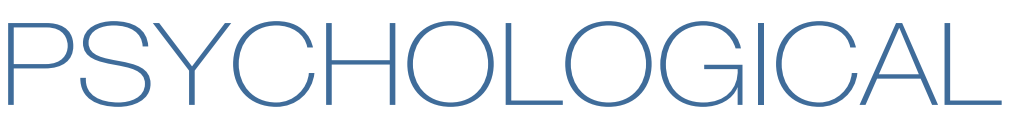

\section{CONTENTS}

In this Issue

\section{REVIEW ARTICLE}

Physical activity and risk of neurodegenerative disease: a systematic review of prospective evidence Hamer M \& Chida Y

\section{ORIGINAL ARTICLES}

The relationship of dementia prevalence in older adults with intellectual disability (ID) to age and severity of ID Strydom A, Hassiotis A, King M \& Livingston G

Dual task performance in early Alzheimer's disease, amnestic mild cognitive impairment and depression

Lonie JA, Tierney KM, Herrmann LL, Donaghey C, O'Carroll RE, Lee A \& Ebmeier KP

Mental-physical co-morbidity and its relationship with disability: results from the World Mental Health Surveys Scott KM, Von Korff M, Alonso J, Angermeyer MC, Bromet E, Fayyad J, de Girolamo G, Demyttenaere K, Gasquet I, Gureje O, Haro JM, He Y, Kessler RC, Levinson D, Medina Mora ME, Oakley Browne M, Ormel J, Posada-Villa J, Watanabe M \& Williams D

Neuroticism, recall bias and attention bias for valenced probes: a twin study

Rijsdijk FV, Riese H, Tops M, Snieder H, Brouwer WH, Smid HGOM \& Ormel $J$

Predictors of first lifetime episodes of major depression in midlife women

Bromberger JT, Kravitz HM, Matthews K, Youk A, Brown C \& Feng $\mathrm{W}$

Antidepressant efficacy of high-frequency transcranial magnetic stimulation over the left dorsolateral prefrontal cortex in double-blind sham-controlled designs: a meta-analysis

Schutter DJLG

Effects of stressor controllability on psychophysiological, cognitive and behavioural responses in patients with major depression and dysthymia

Diener C, Kuehner C, Brusniak W, Struve M \& Flor H
Ethnicity, socio-economic status and self-harm in Swedish youth: a national cohort study

Jablonska B, Lindberg L, Lindblad F \& Hjern A

Decision making and problem solving in adolescents who deliberately self-harm

Oldershaw A, Grima E, Jollant F, Richards C, Simic M, Taylor L \& Schmidt $U$

Lifetime course of eating disorders: design and validity testing of a new strategy to define the eating disorders phenotype Anderluh M, Tchanturia K, Rabe-Hesketh S, Collier D \& Treasure J

Correlated genetic and non-shared environmental influences account for the co-morbidity between female sexual dysfunctions

Witting K, Santtila P, Rijsdijk F, Varjonen M, Jern P, Johansson A von der Pahlen B, Alanko K \& Sandnabba NK

The prevalence of premenstrual dysphoric disorder in a randomly selected group of urban and rural women

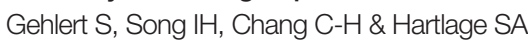

The prevalence and workplace costs of adult attention deficit hyperactivity disorder in a large manufacturing firm Kessler RC, Lane M, Stang PE \& Van Brunt DL

Alcohol and illicit drug dependence among parents: associations with offspring externalizing disorders Marmorstein NR, lacono WG \& McGue M

Does the 'gateway' matter? Associations between the order of drug use initiation and the development of drug dependence in the National Comorbidity Study Replication Degenhardt L, Chiu WT, Conway K, Dierker L, Glantz M, Kalaydjian A, Merikangas K, Sampson N, Swendsen J \& Kessler RC

Correspondence

BOOK REVIEW

Integrated Management of Depression in the Elderly Dening $T$ 